\title{
Seismic Analysis of a Ten-Storey Reinforced Concrete Building in Jazan Area, KSA
}

\author{
A. E. Hassaballa1, Fathelrahman Mohammed Adam, ${ }^{1,2}$, M. A. Ismaeil ${ }^{3,4}$ \\ ${ }^{1}$ Department of Civil Engineering, Jazan University, Jazan, KSA \\ ${ }^{2}$ Nile Valley University, Atbara, Sudan \\ ${ }^{3}$ Department of Civil Engineering, King Khalid University, Abha, KSA \\ ${ }^{4}$ Sudan University of Science and Technology, Khartoum, Sudan \\ Email: tomali99@yahoo.com
}

How to cite this paper: Hassaballa, A.E., Adam, F.M. and Ismaeil, M.A. (2017) Seismic Analysis of a Ten-Storey Reinforced Concrete Building in Jazan Area, KSA. Open Journal of Civil Engineering, 7, 252-266. https://doi.org/10.4236/ojce.2017.72016

Received: March 21, 2017

Accepted: June 12, 2017

Published: June 15, 2017

Copyright $\odot 2017$ by authors and Scientific Research Publishing Inc. This work is licensed under the Creative Commons Attribution International License (CC BY 4.0).

http://creativecommons.org/licenses/by/4.0/ (c) †) Open Access

\begin{abstract}
Jazan area is located in the most active seismic zone region of the Kingdom of Saudi Arabia where there is a complicated geological structures and tectonics. This project reviews the seismic activities occurred in Jazan area together with reviewing the Saudi Building (Seismic) Code (SBC-301-2007) [1]. A multi-story reinforced concrete building, in Jazan city, was seismically analyzed using the Equivalent Lateral Force Procedure with the aid of STAAD PRO software. The building, which was Ordinary Reinforced Concrete Moment Resisting Frame (ORCMRF), was analyzed in compliance with the provisions of (SBC-301-2007) [1]. The most important parameters governing the analysis of this frame were dead load, live load and seismic loads. Seismic loads were computed as pairs of accelerations versus times. The damping ratio was taken as 0.05 ( $5 \%$ of the critical damping). The ground accelerations versus time periods were calculated using SBC-301-2007 together with parameters necessary to be used as input data for the program to calculate the seismic parameters, i.e., reactions, displacements, base shear, bending moments, shearing forces, drifts. The obtained results show effects of earthquake ground motions on building studied herein are so greater for the higher increases of the values of outputs resulting from seismic loads comparing to that due to static load only. Finally, the results obtained, clearly, show the importance of taking the Saudi seismic code provisions into account when analyzing and designing multi-story buildings in Jazan area.
\end{abstract}

\section{Keywords}

Kingdom of Saudi Arabia, Strengthening, Saudi Building Code (SBC), SAP2000, Seismic Forces

\section{Introduction}

Jizan, or more properly Jazan, was known in ancient times as Almikhlaf Alsuli- 
mani. Jazan is located on the southwest corner of Saudi Arabia on the coast of the Red Sea and directly north of the border with Yemen. Jazan City lies in an active zone of earthquakes classified as zone $2 \mathrm{~B}$ with maximum applied horizontal acceleration of 0.2 g. Saudi Arabia is divided into 25 zones; each zone has its specific building code covering not only seismic activity but other criteria as well.

The Province of Jazan lies in the south west section of the Kingdom of Saudi Arabia. It has a population of approximately 1,365,110 at the 2010 census and covers an area of $40,000 \mathrm{~km}^{2}$ including some 5000 villages and cities. Jizan, is home to the Port of Jizan, Saudi Arabia's third most important port on the Red Sea. It stretches some $300 \mathrm{~km}$ along the southern Red Sea coast, just north of Yemen. The region includes over 100 islands in the Red Sea. The Farasan Islands, Saudi Arabia's first protected wildlife area, is home to the endangered Arabian gazelle and, in winter, receives migratory birds from Europe.

\section{Literature Review}

Many researches and studies, in this area, have been conducted relating to Saudi Arabia in general and southwestern Saudi in particular such as: S.A. Ashour and H.H. Abdel-Rahman, in 1994, who presented a paper on "Application of Seismic Risk Analysis and Earthquake Simulation Methods to the Western Region in Saudi Arabia” [2].

A comparative study on seismic provisions made in UBC-1997 and Saudi building code (SBC-301-2007) for RC buildings was prepared by Nazar and M. A. Ismaeil (2014) [3]. A technical report on "Earthquakes Data Base of the Arabian peninsula" was written by Abdullah M. Alamri in 1998 [4]. The report describes the seismological problems associating with rifting in the Red Sea and the geometry of the plate margins in the west and southwest. Abdullah M. Al-Amri, Arthur J. Rodgers, Tariq A. Al-Khalifa, presented a paper on "Improving the level of seismic hazard parameters in Saudi Arabia using earthquake location", (2008) [5].

Awad Ali Al-Karni (2009) [6], studied the evaluation of the liquefaction potential of the soil at the location of Jazan university in Jazan city which lies on the east side of Red Sea. M.N. Fatani and A.M. Khan (1993) [7], presented a conference paper on "Foundation on salt bearing soils of Jizan", in order to present the geotechnical aspects of the area concentrating on the foundation design and construction practice. Furthermore, the geotechnical aspects of Jazan soil were studied by many authors as (Dhowian et al., 1987 [8]; Erol, 1989 [9]; Dhowian, 1990 [10]; Al-Shamrani and Dhowian, 1997) [10].

\section{Earthquakes Data Base of the Arabian Peninsula}

Recently, there are two independent analog seismic telemetry networks in Saudi Arabia. The King Saud University (KSU) network was established in 1985 and consists of 30 stations with denser sub-networks in the Gulf of Aqabah region (12 stations) and the southwestern part of Saudi Arabia (8 stations). A network 
run by King Abdulaziz City for Science and technology (KACST) was established in 1993 with 11 short-period stations in the Gulf of Aqabah and the southwestern part of Saudi Arabia adjacent to the Yemen border. Saudi Arabia will set up an additional 50 advanced earthquake monitoring stations. The Kingdom already has 150 earthquake monitoring stations called the Saudi National Seismic Network (SNSN), and the new ones will boost the capability by providing precise data collection [11]. Figure 1 shows the distribution of seismograph stations of Saudi Arabia [12].

\section{Samples of Earthquakes in Jazan Area}

In 2014, a magnitude-5.1 earthquake struck in the southwestern part of the Kingdom, $50 \mathrm{~km}$ northeast of Jazan, at a depth of $10 \mathrm{~km}$ followed by 37 aftershocks of magnitudes ranging 0.94 - 5.1 in Richter scale [12].

Its impact was felt by inhabitants in the Asir and Najran regions. Generally, there were many earthquakes struck Jazan area and north of Yemen in the years 859, 1121, 1191, 1269, 1481, 1630, 1710, 1941, 1947 (of magnitude 6, killed 1200 of people), 1955, 1982, 1993 (of magnitude 4.8) as shown in Figure 2. Earthquakes of magnitude 6 are common along the spreading axis of the Red Sea but generally they are not felt onshore and appear to pose little risk to infrastructure [12].

Figure 2 shows earthquake epicenters greater than magnitude 3 in the Saudi

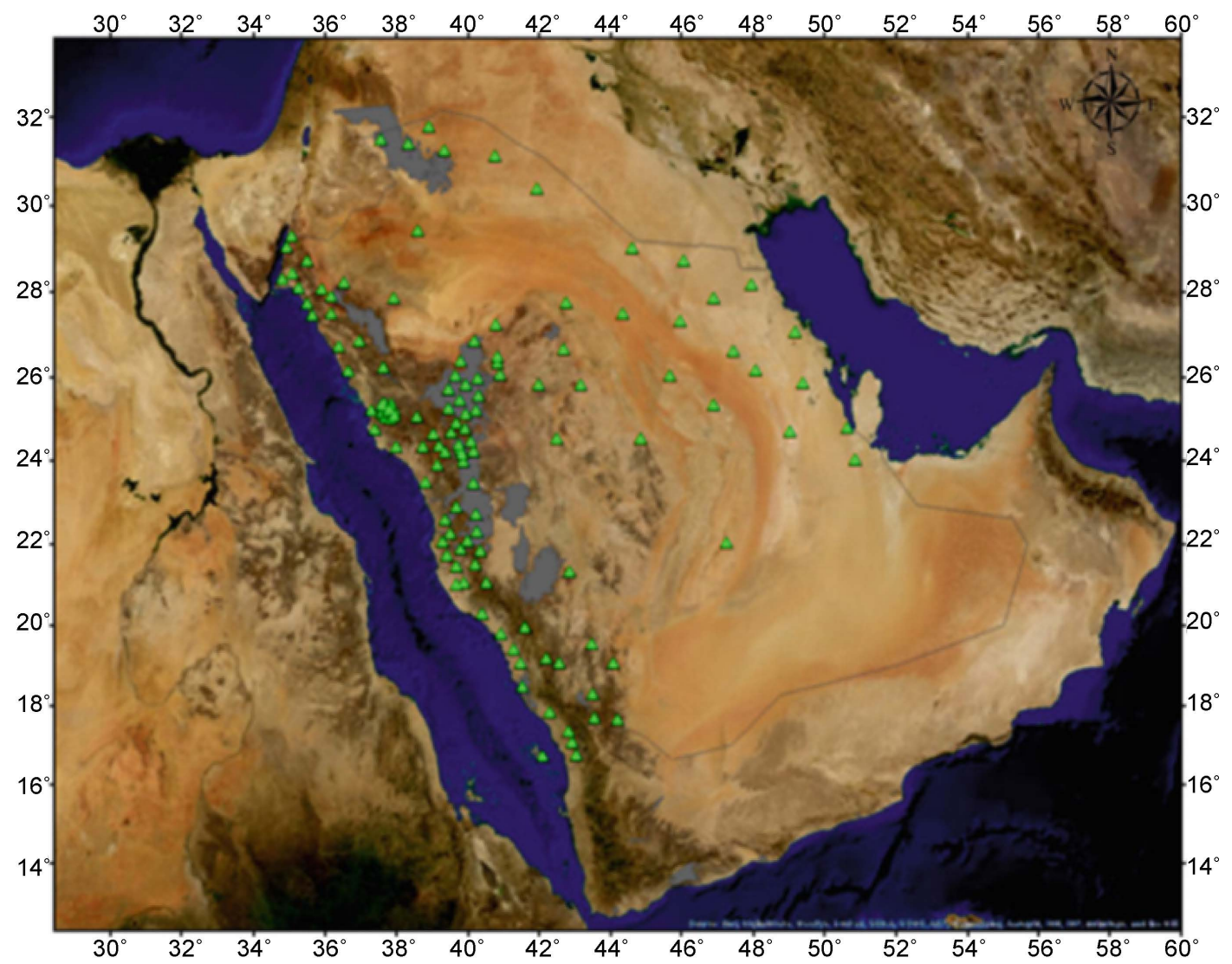

Figure 1. Seismograph stations of the Saudi National Seismic Network. 
Geological Survey (SGS) catalogue for all years up to 2013. Figure 3 shows the distribution of instrumental earthquakes in Jazan area and its vicinity.

\section{Description of the Building}

The investigated building is a multi-story reinforced concrete structure used as

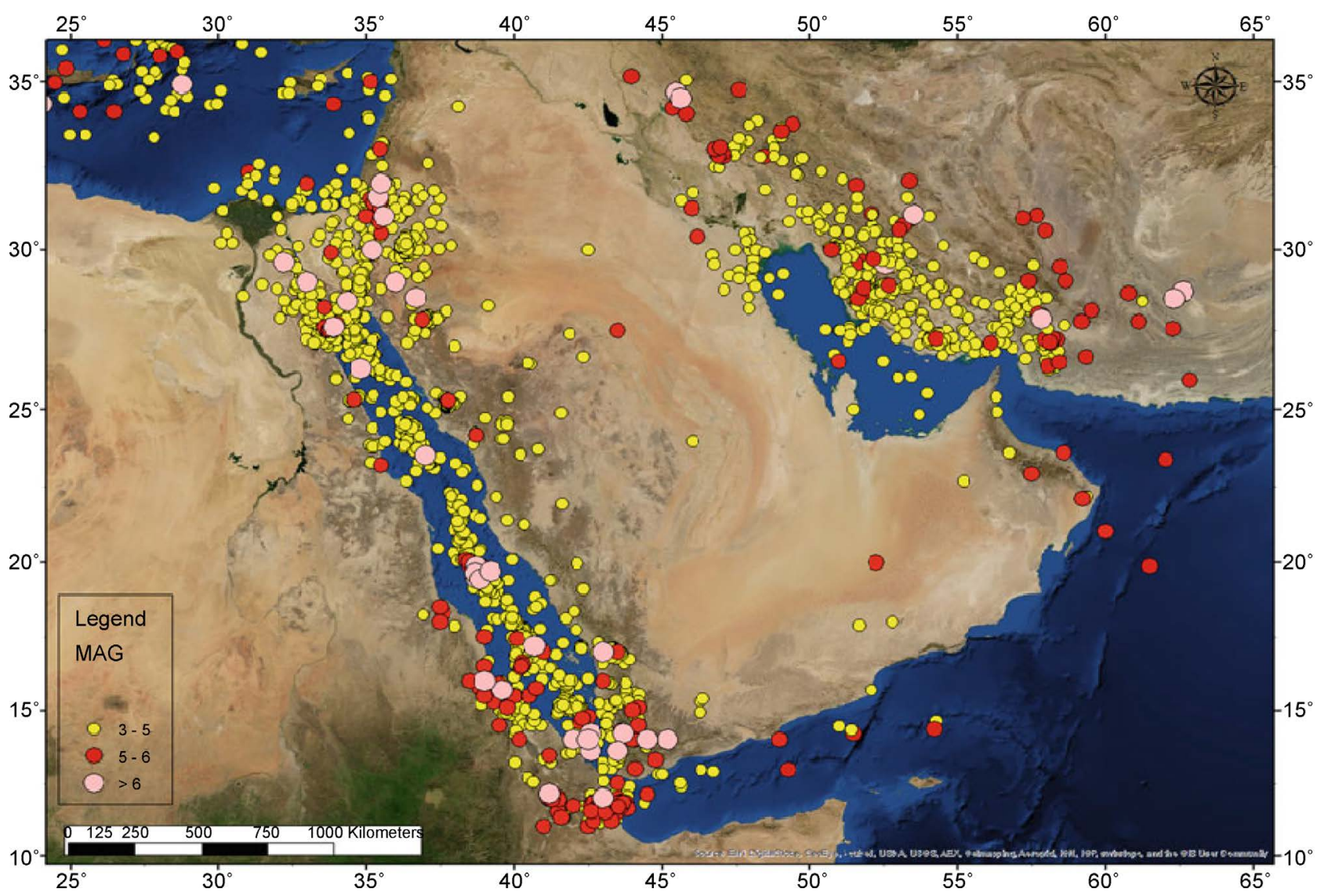

Figure 2. Seismicity up to 2013 including historical and instrumental earthquakes above Ml 3 (Saudi geological survey database).

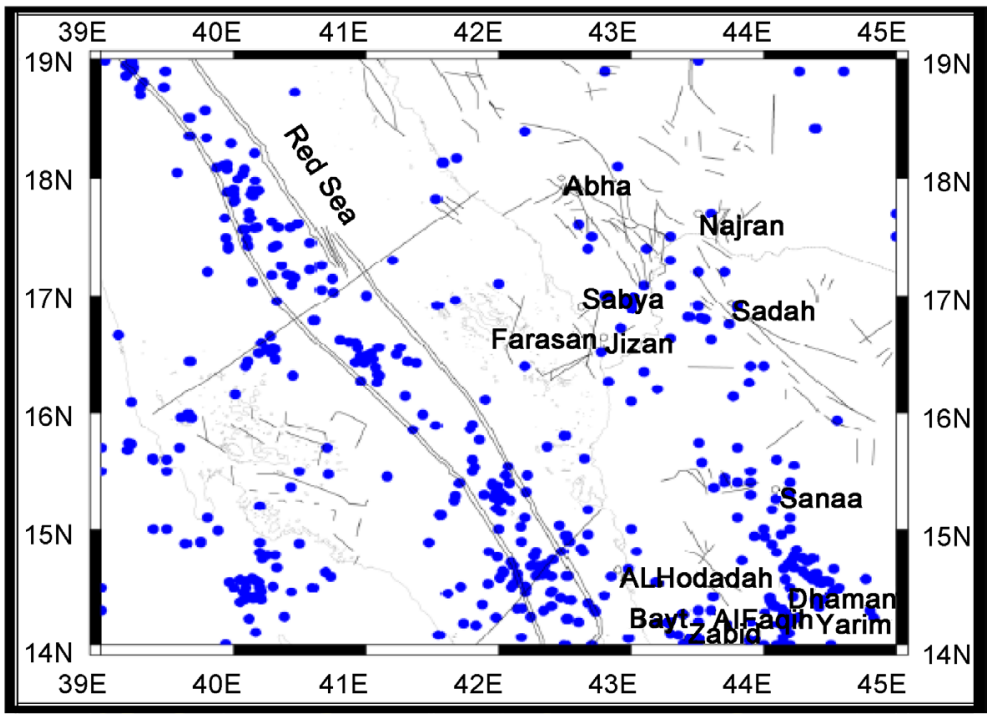

Figure 3. Distributed of instrumental earthquakes in Jazan area and vicinity. 
offices building and located in Jazan city. The elevation of the building is shown in Figure 4. The building has 10 stories above ground level. The total height of the building is $30 \mathrm{~m}$ of $3 \mathrm{~m}$ per story height.

The dimensions of the building are $16 \mathrm{~m}$ in the X-Direction of equal 4-bays and $20 \mathrm{~m}$ in the Z-Direction of equal 5-bays. The structural system consists of rigid frames and only the XY plane frame was used in the analysis. The cross sections of the construction elements are as follows:

- Typical columns sections $=300 \mathrm{~mm} \times 300 \mathrm{~mm}$,

- Typical beams sections $=300 \mathrm{~mm} \times 450 \mathrm{~mm}$, and

- Typical slab thickness $=150 \mathrm{~mm}$.

The main analysis method was the modal response spectrum analysis with taking 5\% damping ratio of the critical value. The analysis was performed with the STAAD-Pro software. The ground accelerations versus time periods were calculated using SBC-301-2007 provision together with other necessary parameters needed to complete the analysis.

The most important parameters governing the analysis of this frame were dead load, live load and seismic loads. As per SBC-301-2007 the following selected load combinations were selected for the analysis of the studied frame:

Load Case $1(\mathrm{~L} / \mathrm{C} 1)$ is static load (dead and live):

$$
1.4(\mathrm{DL}+\mathrm{LL})
$$

Load Case $2(\mathrm{~L} / \mathrm{C} 2)$ is static load + Earthquake loads:

$$
1.2 \mathrm{DL}+1.0 \mathrm{E}+\mathrm{f} 1 \mathrm{LL}
$$

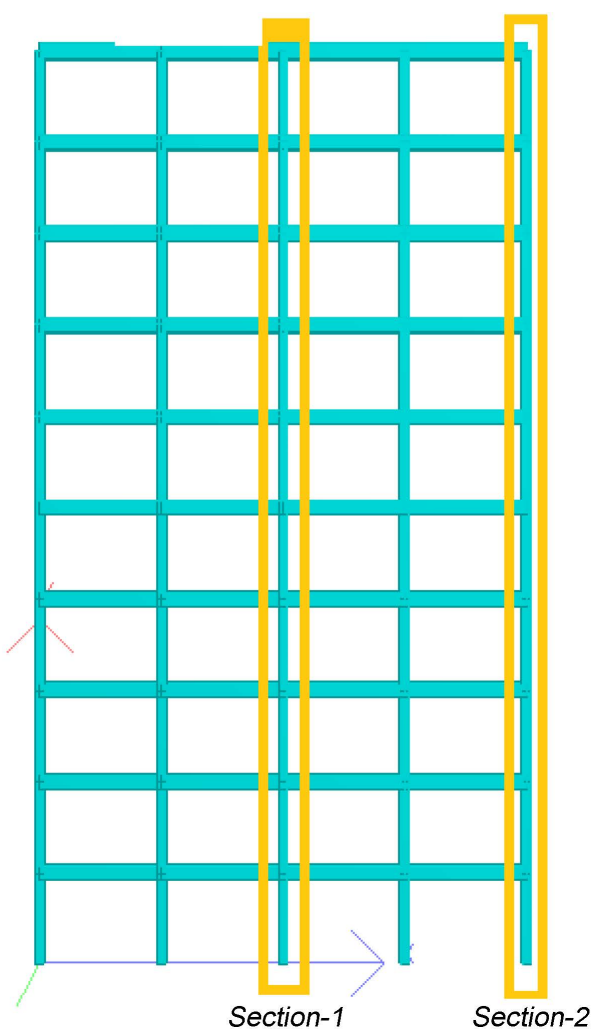

Figure 4. XY-plane of the studied building. 
Load Case 3 (L/C3) is dead + Earthquake loads:

$$
0.9 \mathrm{DL}+1.0 \mathrm{E}
$$

where

$\mathrm{f} 1=1.0$ for areas occupied as places of public assembly, for live loads in excess of $0.5 \mathrm{kN} / \mathrm{m}^{2}$ and for parking garage live load.

$\mathrm{f} 1=0.5$ for other live loads.

In this analysis, the live load is taken as $3.5 \mathrm{kN} / \mathrm{m}^{2}$.

From the frame shown in Figure 4, section-1 and section-2 were selected to summarize the main results for the different loading cases.

\section{Seismic Loads According to Saudi Building Code (SBC-301-2007)}

The horizontal seismic loads are defined according to Saudi Building Code (SBC-301-2007). The lateral force effect on the structure can be translated to equivalent lateral force at the base of the structure which can be distributed to different stories. According to Saudi Building Code (SBC-301-2007), the total seismic base shear force $V$ is determined as follows:

$$
V=C_{s} * W
$$

where: $C_{s}$ is the seismic coefficient, $W$ is the total weight and $V$ is the base shear. The seismic design coefficient $\left(C_{s}\right)$ shall be determined in accordance with the following equation:

$$
C_{s}=S_{D S} /(R / I)
$$

where, $S_{D S}=$ Design spectral response acceleration in the short period range,

$R=$ Response modification factor,

$I=$ Occupancy importance factor determined.

The value of the seismic response coefficient, $\left(C_{s}\right)$, need not be greater than the following equation:

$$
C_{s}=S_{D 1} /[T(R / I)]
$$

$T=$ Fundamental period of the structure $(\mathrm{sec})$

$$
T=0.1 N
$$

But shall not be taken less than.

$$
C_{s}=0.044 S_{D S} I
$$

Design earthquake spectral response acceleration at short periods, $S_{D S}$ and at 1-sec period, $S_{D 1}$, shall be as follows.

$$
\begin{gathered}
S_{M S}=F_{a} * S_{S} \\
S_{M 1}=F_{v} * S_{1} \\
S_{D S}=2 / 3 * S_{M S} \\
S_{D 1}=2 / 3 * S_{M 1}
\end{gathered}
$$

where:

$S_{S}$ : the maximum spectral response acceleration at short periods (determined 
from the $0.2 \mathrm{sec}$.).

$S_{1}$ : the maximum spectral response acceleration at a period of $1 \mathrm{sec}$.

$F_{a}$ : acceleration-based site coefficient.

$F_{r}$ v velocity-based site coefficient.

$S_{M s}$ the maximum spectral response acceleration at short periods adjusted for site class.

$S_{M 1}$ : the maximum spectral response acceleration at a period of $1 \mathrm{sec}$ adjusted for site class.

$S_{D S}$ the design spectral response acceleration at short periods.

$S_{D 1}$ : the design spectral response acceleration at a period of $1 \mathrm{sec}$, in units of g-sec.

\section{Design Response Spectra}

The design response spectra curve, as indicated in Figure 5, shall be developed as follows:

For period less than or equal to $T_{0}$, the design response spectra acceleration, $\mathrm{Sa}$, shall be taken as given by:

$$
S_{a}=S_{D S}\left(0.4+0.6\left(\frac{T}{T_{0}}\right)\right)
$$

For periods greater than or equal to $T_{0}$ and less than or equal to $T_{\mathcal{S}}$ the design response spectra acceleration, $S_{a}$, shall be taken as equal to $S_{D s}$ :

For periods greater than $T_{S}$ the design response spectra acceleration, $S_{a}$, shall be taken as equal to $S_{D S}$ :

$$
S_{a}=S_{D 1} / T
$$

where

$$
\begin{gathered}
T_{0}=0.2 S_{D 1} / S_{D S} \\
T_{S}=S_{D 1} / S_{D S}
\end{gathered}
$$

\section{Vertical Distribution of Base Shear}

The buildings are subjected to a lateral load distributed across the height of the building based on the following formula specified by Saudi Building Code

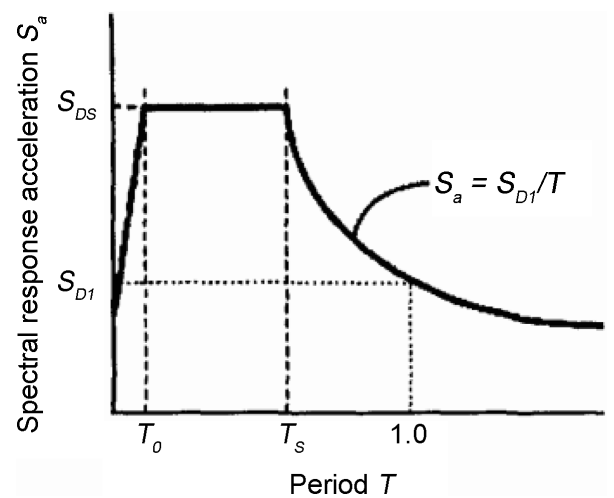

Figure 5. Design response spectra. 
(SBC-303-2007):

$$
\frac{w_{x} h_{x}^{k}}{\sum_{i=1}^{n} w_{i} h_{i}^{k}}
$$

where, $F_{x}$ is the applied lateral force at level " $x$ ", $W$ is the storey weight, $h$ is the story height and $V$ is the design base shear, and $N$ is the number of stories. The summation in the denominator is carried through all story levels. This results in an inverted triangular distribution when $k$ is set equal to unity. A uniform lateral load distribution consisting of forces that are proportional to the story masses at each story level.

$k=$ an exponent related to the structure period as follows:

For structures having a period of $0.5 \mathrm{sec}$ or less, $k=1$,

For structures having a period of $2.5 \mathrm{sec}$ or more, $k=2$.

\section{Seismic Map for the Kingdom of Saudi Arabia}

The Saudi Building Code (SBC-303-2007) provides seismic maps for the Kingdom of Saudi Building. Figure 6 and Figure 7 show the seismic maps for region 6 in which Jazan area lies.

\section{Results of the Analysis}

\subsection{Calculations of Mapped and Design Spectral Response Accelerations for the Jazan City}

Using the Saudi Building Code (SBC-301-2007) [1] provisions, the following parameters have been calculated to be used as input data for seismic analysis of the selected model with notice that the Jazan City falls in region 6 . The calculated results of these parameters are as follows:

From Table 1 and since $S_{D S}<0.167 \mathrm{~g}$ and $S_{D 1}<0.067 \mathrm{~g}$, the seismic design category for Jazan cityis category A (See Table 2).

$R=2.5$ (for ordinary R.C. resisting moment frame),

$I=$ the occupancy importance factor determined in accordance with section 9.5 (SBC-301-2007),

$I=1$ (for occupancy category I and II),

A total time of vibration of 10 seconds taken as time interval of 0.025 second was considered for the analysis.

\subsection{Results of the Analysis}

The obtained results from the analyzing the frame were taken only for the two sections 1 and 2 as shown in Figure 4. Section-1 gives maximum values of axial loads of columns through the height of the frame. Section-2 gives maximum values of shear forces and bending moments for the columns from ground floor to the tenth floor.

The load combination 1 (Static, dead load plus live load) (L/C1), gives maximum axial forces through section-1, which were greater in columns at floor level and decreased gradually for the highest columns respectively. A comparison 


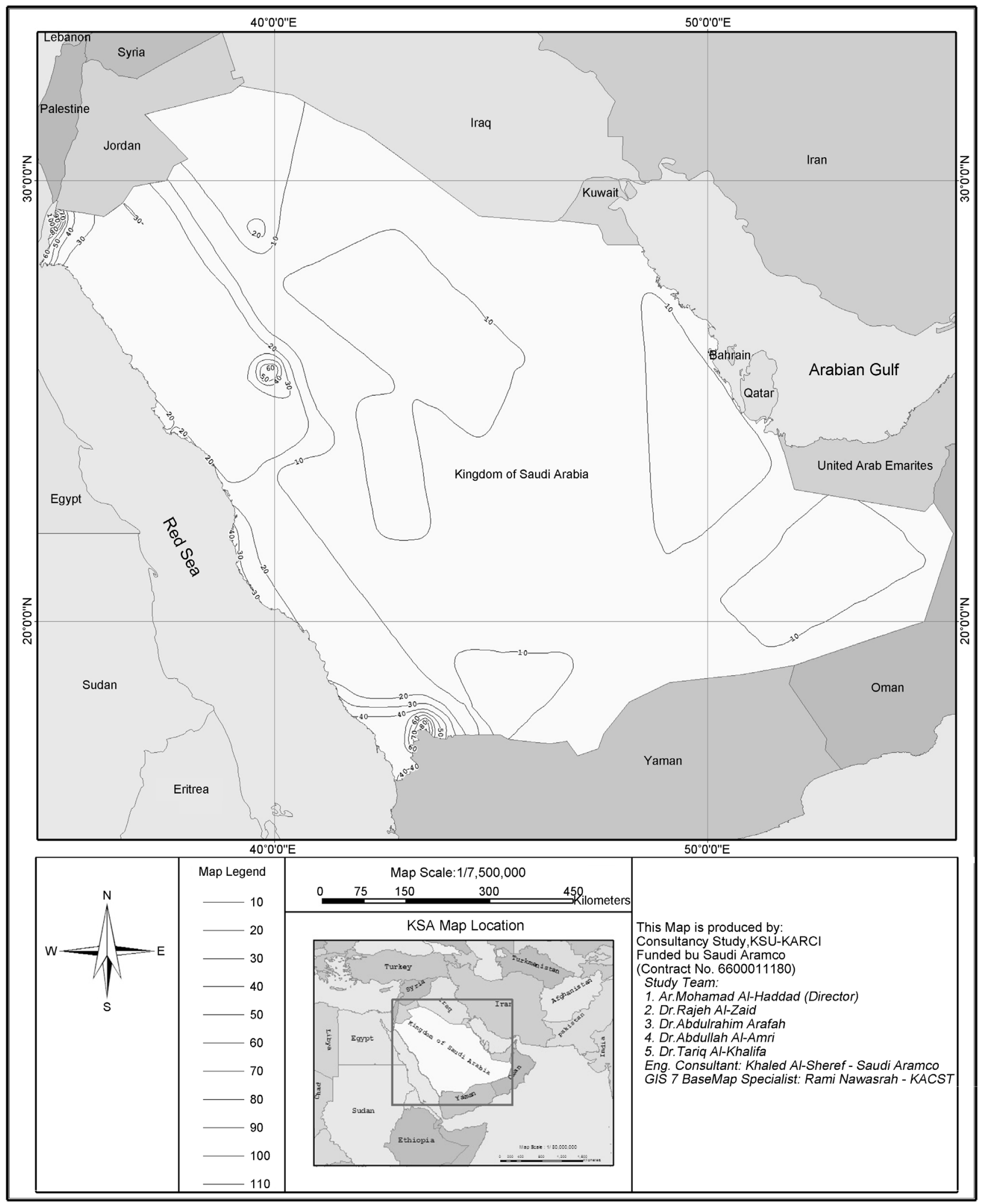

Figure 6. Maximum considered earthquake ground motion for the kingdom of 0.2 SEC spectral response acceleration $\left(S_{S}\right.$ in $\left.\% \mathrm{~g}\right)$ (5 percent of critical damping), site class B. (region 6).

between the values of axial loads for the columns along section-1 is clearly explained in Figure 8. 


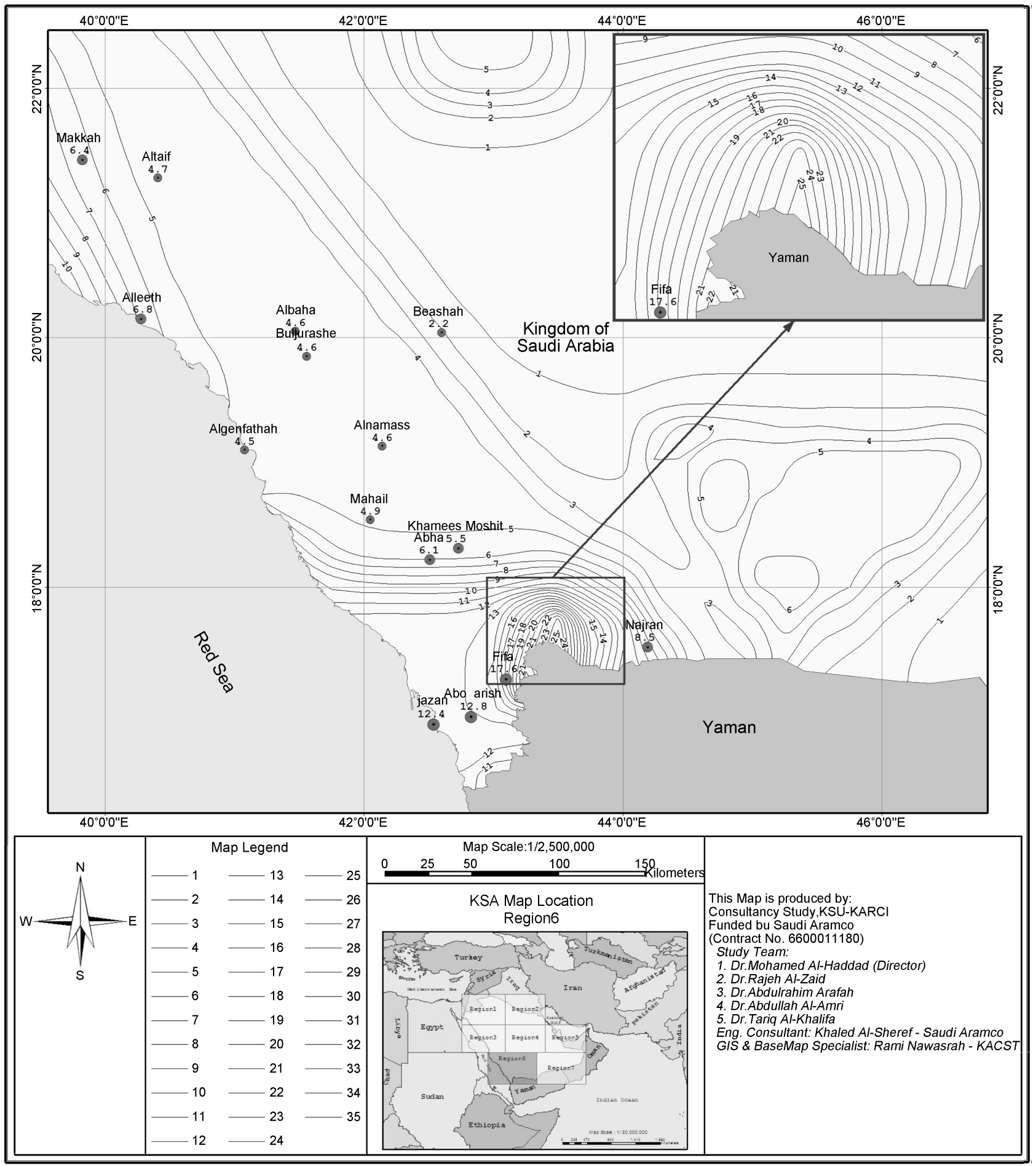

Figure 7. Maximum considered earthquake ground motion for the kingdom of 1 SEC spectral response acceleration $\left(S_{1}\right.$ in $\left.\% \mathrm{~g}\right)(5$ percent of critical damping), site class B. (region 6).

The shear forces for the columns falling in section-2 were comprised for the three load combinations and load combination 2 (L/C2) (dead + live + seismic) gives maximum values from the ground floor to the 8th floor. Also the values of combination 3 (L/C3) showed greater than the values of combination 1 up to the 8th floor level. This is clearly shown in Figure 9. 
Table 1. Seismic parameter for Jazan city according to SBC301.

\begin{tabular}{ccccccc}
\hline City & $S_{S}$ & $S_{1}$ & $F_{a}$ & $F_{V}$ & $S_{M S}$ & $S_{M 1}$ \\
\hline Jazan & 0.435 & 0.124 & 1.908 & 3.428 & 0.830 & 0.425 \\
\hline$S_{D S}$ & $S_{D 1}$ & $T$ & $R$ & Cs req & Cs max & Cs min \\
\hline 0.553 & 0.283 & 1.000 & 2.5 & 0.221 & 0.113 & 0.024 \\
\hline
\end{tabular}

Table 2. Samples of the calculated accelerations versus times for the Jazan city.

\begin{tabular}{ccc}
\hline No. & Time Interval $(\mathrm{sec})$ & Accelerations $\left(\mathrm{m} / \mathrm{s}^{2}\right)$ \\
\hline 1 & 1.000 & 0.283 \\
2 & 2.000 & 0.142 \\
3 & 3.000 & 0.094 \\
4 & 4.000 & 0.071 \\
5 & 5.000 & 0.057 \\
6 & 6.000 & 0.047 \\
7 & 7.000 & 0.040 \\
8 & 8.000 & 0.035 \\
9 & 9.000 & 0.031 \\
10 & 10.000 & 0.028 \\
\hline
\end{tabular}

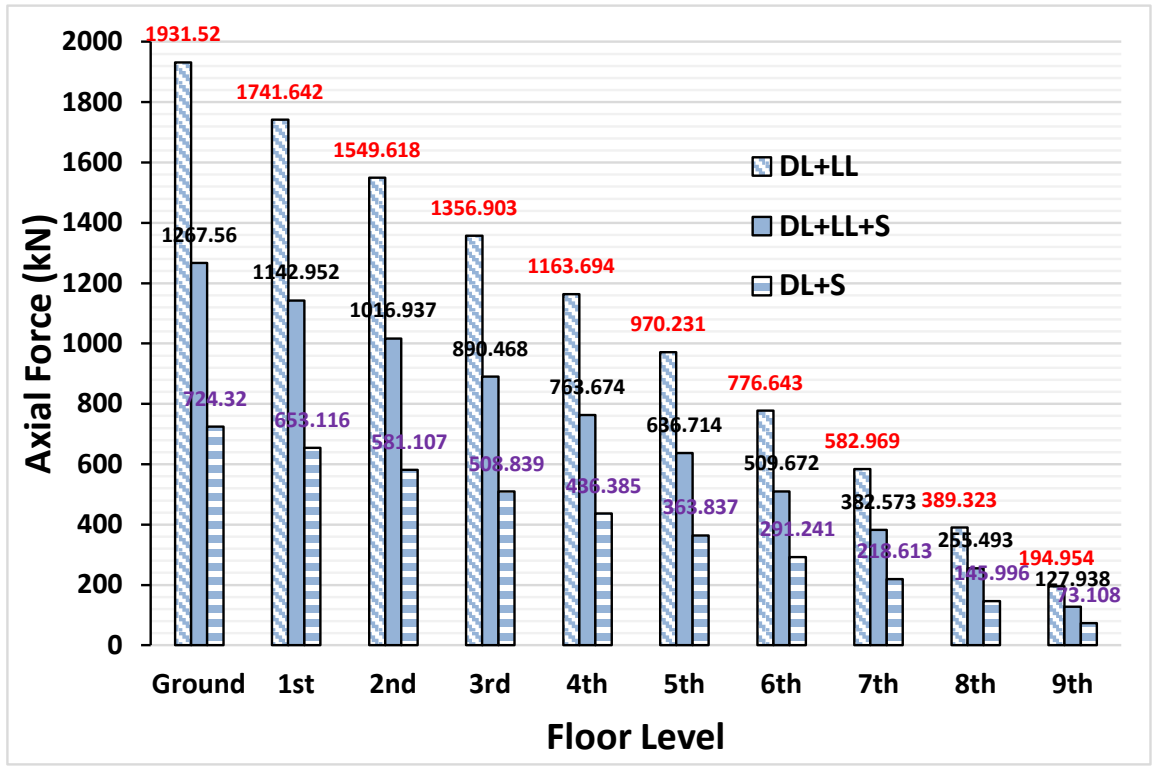

Figure 8. A comparison between axial forces of the columns falling in section-1 for the three load combinations.

For the purpose of reflecting the importance of including seismic loads, percentage difference were carried out to explain the difference between the shear forces obtained due to $\mathrm{L} / \mathrm{C} 1$ and $\mathrm{L} / \mathrm{C} 2$ with referred to static load. The comparison is shown in Figure 10.

Note that:

$$
\text { Diff } 1 \%=\frac{\text { Shear Force }(\mathrm{L} / \mathrm{C} 2)-\text { Shear Force }(\mathrm{L} / \mathrm{C} 1)}{\text { Shear Force }(\mathrm{L} / \mathrm{C} 1)}
$$




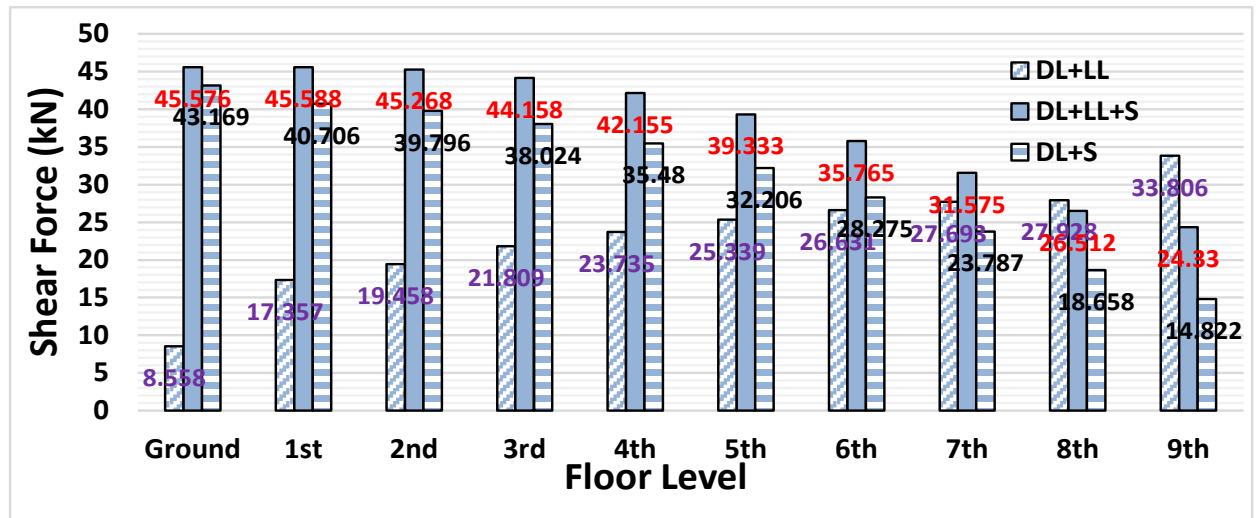

Figure 9. A comparison of shear forces of the columns falling in section-2 for the three load combinations.

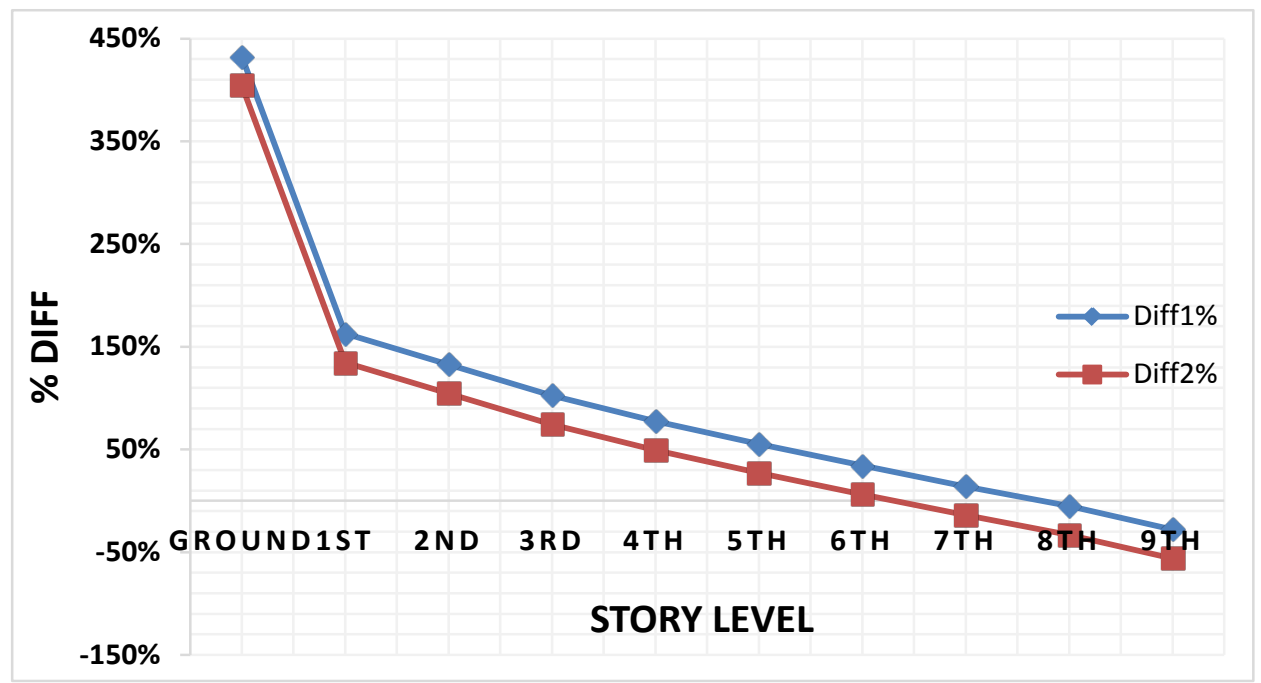

Figure 10. The percentage differences between the shear forces of the columns topped up in section-2 for the load combinations including L/C2 and L/C1.

$$
\text { Diff 2\% }=\frac{\text { Shear Force }(\mathrm{L} / \mathrm{C} 3)-\text { Shear Force }(\mathrm{L} / \mathrm{C} 1)}{\text { Shear Force }(\mathrm{L} / \mathrm{C} 1)}
$$

The bending moments for the columns falling in section-2 were compared for the three loads combinations. As for shear forces, the load combination 2 (dead + live + seismic) gave maximum values varied from the ground floor to the 8th floor. Also the values of $\mathrm{L} / \mathrm{C} 3$ showed greater values than that due to $\mathrm{L} / \mathrm{C} 1$ up to the 8th floor level. This is clearly shown in Figure 11.

As done for shear forces, percentage differences were carried out to explain the differences between the bending moments obtained due to $\mathrm{L} / \mathrm{C} 1$ and $\mathrm{L} / \mathrm{C} 2$ with referring to the static load. The comparison is shown in Figure 12.

The displacements taken here are only the horizontal displacements due to seismic loads and have the same values for the two combinations and also are same for the two sections. The maximum displacements, normally occurred, at the top of frame with a value of $76.5 \mathrm{~mm}$. the values of displacements through the height of the frame can be shown in Figure 13. 


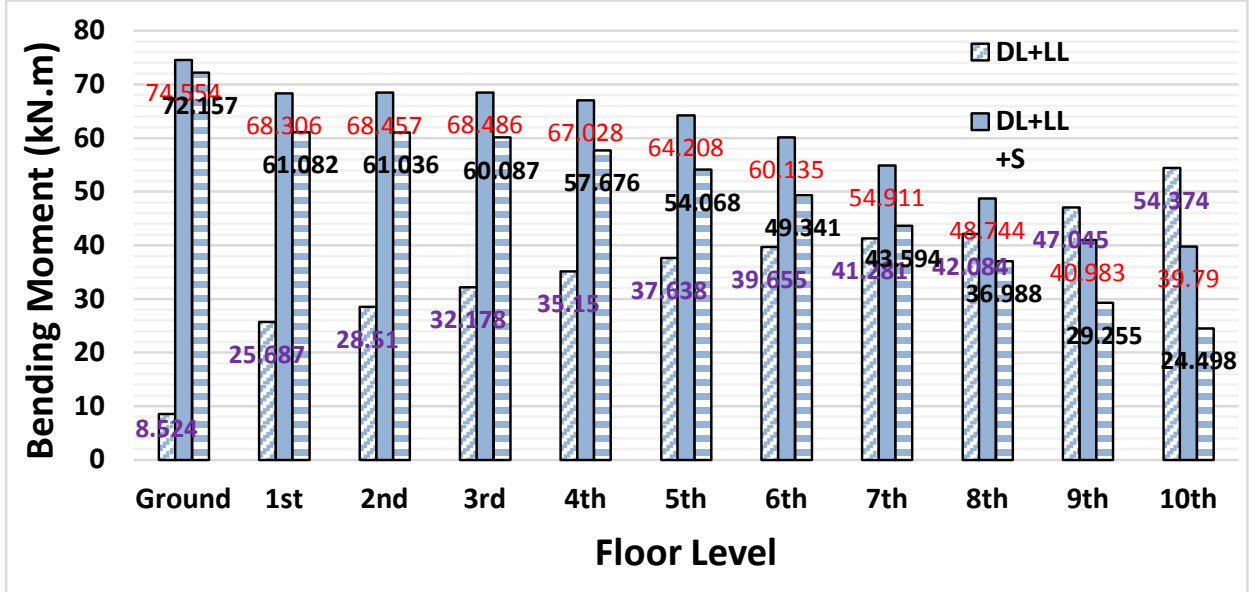

Figure 11. A comparison between bending moments of the columns falling in section- 2 for the three load combinations.

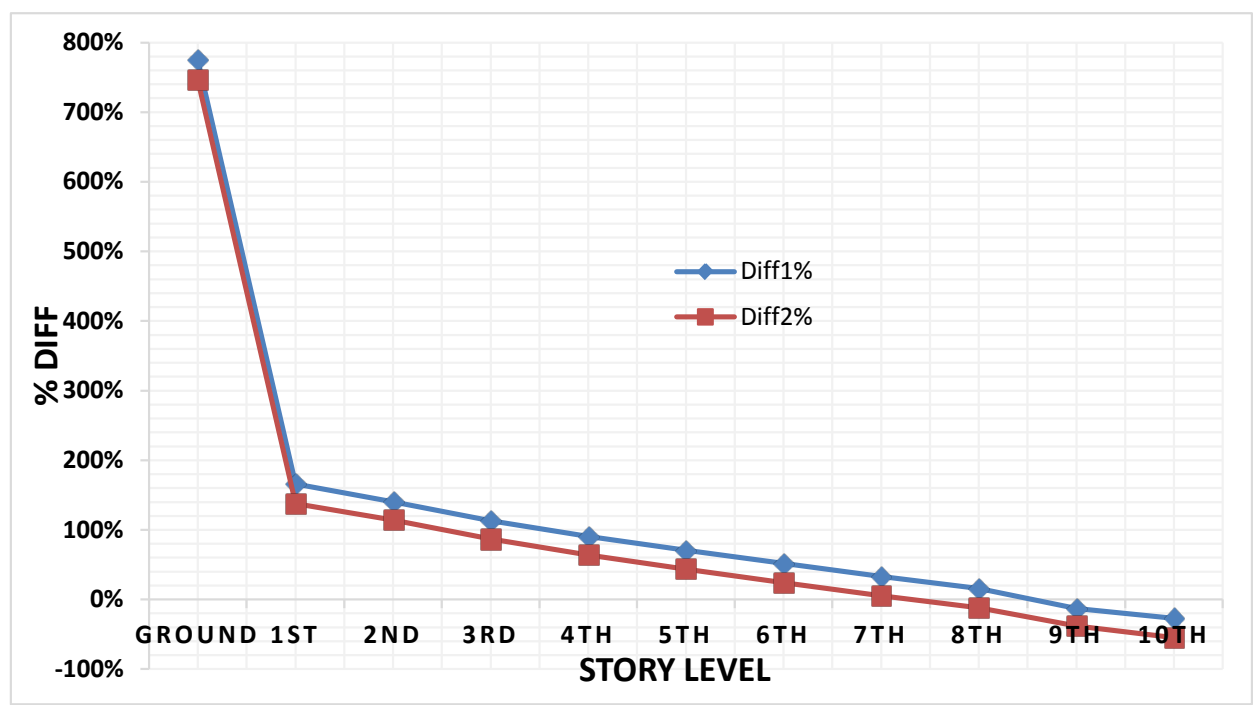

Figure 12. The percentage differences between the bending moments of the columns topped up in section-2 for the load combinations $\mathrm{L} / \mathrm{C} 2$ and $\mathrm{L} / \mathrm{C} 1$.

\section{Conclusions}

Most buildings in Jazan area have not been analyzed and designed with compliance of the Saudi Seismic Code. Based on the obtained results from the analysis of the studied frame in Jazan city, it can be concluded that:

1) It is found that the values of horizontal support reactions generating from $\mathrm{L} / \mathrm{C} 2$ were about 8 times that due to $\mathrm{L} / \mathrm{C} 1$ in the outer supports and this rate increases much more in the inner supports.

2) It is clearly observed that the calculated resultant of nodal displacements due to $\mathrm{L} / \mathrm{C} 2$ was about 6 to 8 times the nodal displacements due to $\mathrm{L} / \mathrm{C} 1$.

3) Axial forces of columns due to $\mathrm{L} / \mathrm{C} 1$ are slightly greater than that due to $\mathrm{L} / \mathrm{C} 2$ and these forces decrease gradually in the upper floor columns.

4) The shear forces obtained in the ground floor level due to seismic loads (L/C2) were about four times of that obtained due to static loads only (L/C1). 


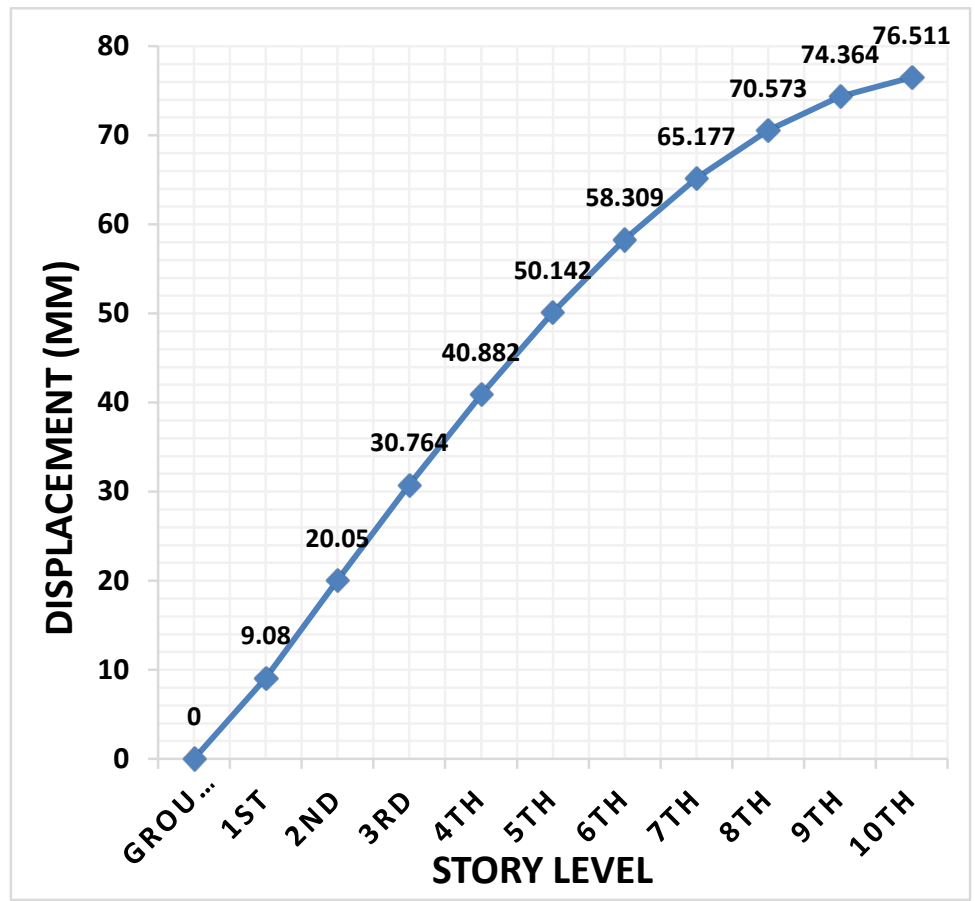

Figure 13. The horizontal displacements along the height of the frame.

The increasing varies gradually from $1.6(160 \%)$ times for the first level to 0.14 $(14 \%)$ at the $7^{\text {th }}$ level. For levels $8^{\text {th }}, 9^{\text {th }}$ and $10^{\text {th }}$, the values of shear forces due to static loads are greater than that due to seismic loads.

5) The maximum bending moments obtained due seismic load were approximately found to be eight times of that obtained by using static loads. As in the shear forces, the values of bending moments due seismic loads (L/C2) are greater through the floor heights, varied from $166 \%$ to $16 \%$ between $1^{\text {st }}$ level to $8^{\text {th }}$ level. For levels 9 th and 10th the bending moments due to static load showed greater values.

\section{References}

[1] Saudi Building Code SBC-301-2007 (2007) Loads and Forces Requirements.

[2] Ashour, S.A. and Abdel-Rahman, H.H. (1994) Application of Seismic Risk Analysis and Earthquake Simulation Methods 2 to the Western Region in Saudi Arabia. JKAU: Eng. Sci., 6, 3-23.

[3] Nazar, S. and Ismaeil, M.A. (2014) A Comparative Study on Seismic Provisions Made in UBC-1997 and Saudi Building Code for RC Buildings. International Journal of Civil, Architectural, Structural and Construction Engineering, 8, 457-463.

[4] Alamri, A.M. (1998) Earthquakes Data Base of the Arabian Peninsula. Technical Report (1), Seismic Studies Center, King Saud University.

[5] Al-Amri, A.M., Rodgers, A.J. and Al-Khalifa, T.A. (2008) Improving the Level of Seismic Hazard Parameters in Saudi Arabia Using Earthquake Location. Arabian Journal of Geosciences, 1, 1-15. https://doi.org/10.1007/s12517-008-0001-5

[6] Al-Karni, A.A. (2009) A Procedure in Engineering Analysis to Evaluate the Liquefaction Potential of the Soil at the University of Jazan City in the Southwest of Saudi Arabia, University of Putra Malaysia. Alam Cipta, 4. 
[7] Fatani, M.N. and Khan, A.M. (1993) Foundation on Salt Bearing Soils of Jizan. 3rd International Conference on Case Histories in Geotechnical Engineering, Missouri University of and Technology.

[8] Dhowian, A.W., Erol, A.O. and Sultan, S. (1987) Settlement Prediction in Complex Sabkha Soil Profiles. Bulletin of the International Association Engineering Geology, 36, 11-21. https://doi.org/10.1007/BF02600934

[9] Erol, A.O. (1989) Engineering Geological Consideration in Salt Dome Region Surrounded by Sabkha Sediments, Saudi Arabia. Engineering Geology, 26, 215-232. https://doi.org/10.1016/0013-7952(89)90010-0

[10] Dhowian, A.W. (1990) Compressibilty Characteristics of Sabkha Complex. The Arabian Journal for Science and Engineering, 15, 47-63.

[11] Al-Shamrani, M.A. and Dhowian, A.W. (1997) Preloading for Reduction of Compressibility Characteristics of Sabkha Soil Profiles. Engineering Geology, 48, 19-41. https://doi.org/10.1016/S0013-7952(97)81912-6

[12] Saudi Geological Survey. www.sgs.org.sa

\section{Scientific Research Publishing}

Submit or recommend next manuscript to SCIRP and we will provide best service for you:

Accepting pre-submission inquiries through Email, Facebook, LinkedIn, Twitter, etc. A wide selection of journals (inclusive of 9 subjects, more than 200 journals)

Providing 24-hour high-quality service

User-friendly online submission system

Fair and swift peer-review system

Efficient typesetting and proofreading procedure

Display of the result of downloads and visits, as well as the number of cited articles

Maximum dissemination of your research work

Submit your manuscript at: http://papersubmission.scirp.org/

Or contact ojce@scirp.org 